\title{
Hyper-Rich and Hyper-Luxury in China: The Case of the Most Expensive Gated Communities*
}

\author{
Guillaume Giroir \\ University of Orléans, Orléans, France
}

\begin{abstract}
Since 2000, we have published fifteen studies on the Chinese upscale gated communities (in Chinese "haohua bieshu qu” or "shehua bieshu qu”). This research was based on various field surveys around big or medium cities like Beijing, Shanghai, Guangzhou, Shenzhen, or Suzhou, and a theoretical framework. It also led us to carry out a statistical approach by elaborating a complete database on all the China's high-end gated communities. The main aim of the current article is to focus the analysis on the China's most luxurious zones of villas (e.g., Longhu Yiheyuan villas in Beijing, Ziyuan villas in Shanghai...). Indirectly, it appears an efficient way to get information on the still mysterious world of the China's very very rich people, their imaginary, their values, and their dreams. This analysis will be developed through two complementary approaches and parts. Firstly, we will discuss the general notion of luxury in China; we also will highlight the specific features of hyper-rich and hyper-luxury in China. It will describe the social stratification of the rich, their spatial distribution and patterns of consumption. In a more holistic approach, the analysis will put into perspective the special status of the rich in a socialist market economy and their very ambivalent image in the Chinese society. Secondly, it will focus on the notion of "residential hyper-luxury". Through field surveys, the analysis will compare the China's most expensive gated communities and elaborate a typology of hyper-luxurious gated communities by underlining their uniqueness and extreme nature.
\end{abstract}

Keywords: China, rich, luxury, gated communities

\section{Introduction}

Whereas in the world, the number of poor is still huge and social inequalities tend to worsen, a tiny minority of society increasingly enriched, that of the very rich, even very very rich people. To meet the demand for these hyper-rich, the sector of the hyper-luxury is rapidly emerging in the world of luxury. This worldwide trend is observed in developed countries but also and perhaps even more in emerging countries. In fact, since the mid-2000s, it became a very spectacular phenomenon in China, that of over-enrichment and the hyper-luxury. If the numerical weight of super-rich Chinese is still minimal, their financial role is considerable. According to a joint survey conducted in 2009 by the China Merchants Bank and Consultancy Bain and Company, 320,000 wealthy Chinese have at least 10 million Yuan (\$1.46 million) each, and collectively, they represent a combined wealth of 8.8 trillion Yuan, equivalent to 29\% of Chinese GDP (30 trillion Yuan). Moreover, the accelerated emergence of nouveau riches and extreme forms of consumption has heavy social, political and even ethical

\footnotetext{
* Paper presented at the Asian Business and Management Conference, October 2010, Osaka (Japan).

Guillaume Giroir, professor of Economic Geography of China, Département de Géographie, University of Orléans, A consultant of rich and luxury in China, email: ggluxchina1@gmail.com.
} 
stakes for a Confucian society and a still officially communist regime. It raises the central issue of elites, their practices, their values, their role in a society just escaped from thirty years of Maoism.

The main objective of this study is trying to identify the specific world of hyper-rich in China, particularly through their residential practices. It aims to describe, classify, understand and interpret the phenomenon of "residential hyper-luxury". Initially, that topic will be put into a general perspective. This will involve trying to define the concept of hyper-luxury emphasizing its vagueness. The analysis will also present the special world of millionaires and billionaires, and the hyper-luxury in China. Details will be provided on the practices of consumption but also on the special status of super-rich in China and their contrasted perception by the society.

In the second part, we will focus on habitat type and residential practices of super-rich Chinese, which is on areas of private, secured and ultra-luxurious villas. While the gated communities as a whole are beginning to be known (G. Giroir, Pow Choon-Piew, Wu Fulong...), the hyper-luxurious gated communities don't have been so far the subject of any specific study. By definition much less numerous than the gated community of more affordable luxury, their case represents a particular methodological issue. Are these extreme cases totally unique and marginal, or do they represent a market segment whose heuristic value goes far beyond their limited number? We will stand here in the second hypothesis, assuming that these exceptional private residential spaces allow to indirectly understand the practices, values, dreams, the imagination of the rich in their most extreme expression, but also to clearly reveal the dysfunction of transitional China.

\section{Hyper-Rich and Hyper-Luxury: The Case of China}

\section{The Concept of "Hyper-Luxury"}

As for luxury goods in general, the concept of hyper-luxury is poorly defined and definable. There is no unit of measurement to identify with certainty what distinguishes the ultra-luxury to the rest of the luxury sector. The hyper-luxury is part of neologisms coined by the media as "new luxury", "mega-rich", "hyper-rich" to describe the new phenomena of extreme forms of enrichment and consumption patterns. Unlike the process of democratization of luxury when the products become more accessible to the middle class, hyper-luxury represents a sanctuary of products and services virtually inaccessible, except for a tiny minority of society. It refers to tailor-made products, limited edition, premium, totally different from the "mass luxury". The super-luxury is the reign of extravagance, extreme and superlatives. It goes back to some of the very origins of the term "luxury", etymologically, it derived from the Latin "luxus” adjective meaning "excess, debauchery, excessive sumptuousness”. The ultra-luxury renews with the values of perfection, excellence, and rarities that affordable luxury has come to trivialize.

The ultra-luxury is a universal trend, but takes particular forms in emerging countries like Russia, India, Brazil or China. While the old wealthy Europe or America is increasing at a rate of slow and largely mature economies and societies, explosive economies of emerging countries allow accelerated growth of personal wealth. In China, the phenomenon of the nouveau riches is all the more spectacular since the level of development has long been very low. The hyper-luxury is the product of the international star system. The considerable income from some movie stars or pop stars give rise to forms of property investment or consumption patterns of off-standard. Overstatement, whims and exuberance converge to make these international stars as the pillars of an entire industry of media and entertainment.

\section{Millionaires and Billionaires in China: Towards a "New Aristocracy"?}

The increase in the number of millionaires and billionaires is a very recent phenomenon in China. It goes above the mid-2000s, and this has been a strong acceleration. According to the Outlook Weekly of Hurun Rich List, the 
number of Yuan billionaires does not exceed one hundred in 2004 but reached a thousand in 2009. According to the 2010 Hurun Wealth Report, the wealthy Chinese people show a clear differentiation according to the level of income. The report estimates at 875,000 the number of people with 10 million Yuan (\$ 1.46 million) in China in 2009, 6.1\% more than in 2008. Among them, there are 55,000 "super rich" (income above 100 million Yuan) and about 1,900 Yuan billionaires, twice more than in 2008. At the top of the pyramid, 140 people have over 10 billion Yuan. China has more dollar billionaires than any other country except the United States (140 instead of 359).

Nevertheless, the phenomenon of super-rich in China must be relativized. The total assets of the richest Chinese are still only one-tenth those of the richest American. Although hyper-enrichment in China shows some spectacular and transgressive features relatively to the regime and the Maoist period, it is yet an only emerging phenomenon. However, the potential for creation and accumulation of wealth is considerable. The average age of wealthy Chinese is indeed much lower than elsewhere in the world, with 39 years, nearly 15 years younger. Their wealth also increases more rapidly.

The example of some figures of super-rich highlights the unique dynamics of enrichment in a very short period. The richest Chinese in 2009 was Wang Chuanfu, chairman of BYD Co. Ltd., maker of electric cars and batteries, at the head of more than $\$ 5.1$ billion, still embryonic, the electric car industry has already resulted in a considerable personal enrichment. He won more than 102 places compared to 2008. Zhang Yin and her family, owner of the paper recycling company Nine Dragons Paper, occupy the second place. Xu Rongmao, owner of Shimao Property Holdings Ltd., occupies third place. Note that Huang Guangyu, the first place in 2008, fells to 17th in 2009, suffered serious legal troubles.

Table 1 and Figure 1 show the ubiquitous presence of the rich in all the regions and the cities of China. Even as very poor regions like Tibet and Guizhou have their rich. Of the 875,000 Chinese millionaires, 151,000 reside in Beijing, the main place of concentration of wealthy in China, followed by Guangdong and Shanghai. In the whole, these three focus areas gather $48 \%$ of the rich in China. In detail, the distribution of the rich is far to be related with the demographic weight of regions or cities. The two mega-cities of Beijing and Shanghai are clearly over-represented, one being the political capital of the country, while the other is the economic capital. This is also the case of cities such as Shenzhen $(45,600)$, boom town with an explosive economic growth thanks to its Special Economic Zone, Hangzhou (47,300), and Mecca of Chinese culture, or Wenzhou $(20,400)$, cradle of the private entrepreneurship in China. Conversely, some big cities show a very significant under-representation of the rich. These include Tianjin, almost as populated as neighboring Beijing, but with only 14,500 rich, ten times less, Chongqing $(9,700)$ or Shenyang $(7,660)$.

The origin of the fortune of the hyper-rich is not always easy to ascertain because of the confidentiality and sensitivity of the subject. Some are obtained through legal channels, some not. The property has been one of the principal means of wealth accumulation. Industrial and commercial sectors (paper industry, electronics...) have also helped to build enormous fortunes. More recently, new energy enriched a few pioneers. Thus, the leader of the solar Jiangxi Province is ranked fourth for his fortune.

The hyper-rich have very typical consumption patterns of the nouveau riches. They practice sometimes hyper-conspicuous consumption. The general logic is that of the accumulation of luxury goods: luxury cars (Ferrari, Bentley...), jewelry (Cartier, Bulgari, Montblanc...), timepieces (Piaget, Cartier...), designer clothes (Armani, Boss), leather (Vuitton, Gucci), perfume (Dior), yachts, antiques, art. According to the Hurun survey, the richest Chinese have an average of three cars and 4.4 luxury watches. Ferrari, established in China since 2004, has sold 206 cars in 2009, still far from the 1,467 US market (or European: 2,752). The number one jewelry, 
Cartier has 32 stores in China, and 55 to run. Super-rich take their vacation in Hainan (Sanya), Yunnan and Hong Kong or abroad (USA, France...). Their favorite pastime is golf. They send their children to Britain for the school and the U.S. for the university. Some buy homes abroad, notably in the United States.

Table 1

Distribution of Millionaires in China (2009)

\begin{tabular}{|c|c|c|c|}
\hline & Geographical area & Total number of dollar millionaires (10 million Yuan) & No. of millionaires owing 100 million Yuan \\
\hline 1 & Beijing & 151,000 & 9,400 \\
\hline \multirow[t]{3}{*}{2} & Guangdong & 145,000 & 8,200 \\
\hline & Guangzhou & 49,200 & 3,810 \\
\hline & Shenzhen & 45,600 & 3,160 \\
\hline 3 & Shanghai & 122,000 & 7,300 \\
\hline \multirow[t]{4}{*}{4} & Zhejiang & 116,500 & 6,760 \\
\hline & Hangzhou & 47,300 & 2,590 \\
\hline & Wenzhou & 20,400 & 2,130 \\
\hline & Ningbo & 13,500 & 860 \\
\hline \multirow[t]{3}{*}{5} & Jiangsu & 62,600 & 4,300 \\
\hline & Nanjing & 22,100 & 1,680 \\
\hline & Suzhou & 15,600 & 930 \\
\hline \multirow[t]{3}{*}{6} & Fujian & 33,500 & 2,100 \\
\hline & Xiamen & 11,500 & 640 \\
\hline & Fuzhou & 10,200 & 540 \\
\hline \multirow[t]{2}{*}{7} & Shandong & 30,500 & 1,720 \\
\hline & Qingdao & 11,100 & 570 \\
\hline \multirow[t]{3}{*}{8} & Liaoning & 26,800 & 1,710 \\
\hline & Dalian & 11,000 & 690 \\
\hline & Shenyang & 7,660 & 510 \\
\hline \multirow[t]{2}{*}{9} & Sichuan & 22,100 & 1,520 \\
\hline & Chengdu & 13,500 & 730 \\
\hline 10 & Henan & 15,200 & 1,040 \\
\hline 11 & Hebei & 14,500 & 1,110 \\
\hline 11 & Tianjin & 14,500 & 1,030 \\
\hline 13 & Shanxi & 13,300 & 1,110 \\
\hline 14 & Hubei & 12,500 & 900 \\
\hline 14 & Hunan & 12,500 & 670 \\
\hline 16 & Shaanxi & 11,000 & 680 \\
\hline 17 & Inner Mongolia & 10,200 & 700 \\
\hline 18 & Chongqing & 9,700 & 650 \\
\hline \multirow[t]{2}{*}{19} & Heilongjiang & 9,600 & 670 \\
\hline & Harbin & 5,790 & 370 \\
\hline 20 & Jiangxi & 8,200 & 680 \\
\hline 21 & Anhui & 7,100 & 760 \\
\hline 22 & Jilin & 6,300 & 430 \\
\hline 23 & Yunnan & 4,800 & 430 \\
\hline 24 & Guangxi & 4,600 & 330 \\
\hline 25 & Hainan & 3,500 & 130 \\
\hline 26 & Guizhou & 2,700 & 240 \\
\hline 27 & Xinjiang & 2,600 & 210 \\
\hline 28 & Ningxia & 700 & 80 \\
\hline 29 & Gansu & 650 & 70 \\
\hline 30 & Qinghai & 500 & 40 \\
\hline \multirow{2}{*}{31} & Tibet & 350 & 30 \\
\hline & Total & 875,000 & 55,000 \\
\hline
\end{tabular}

Note. Source: 2010 Hurun Wealth Report, Hurun Research Institute, April 2010. 


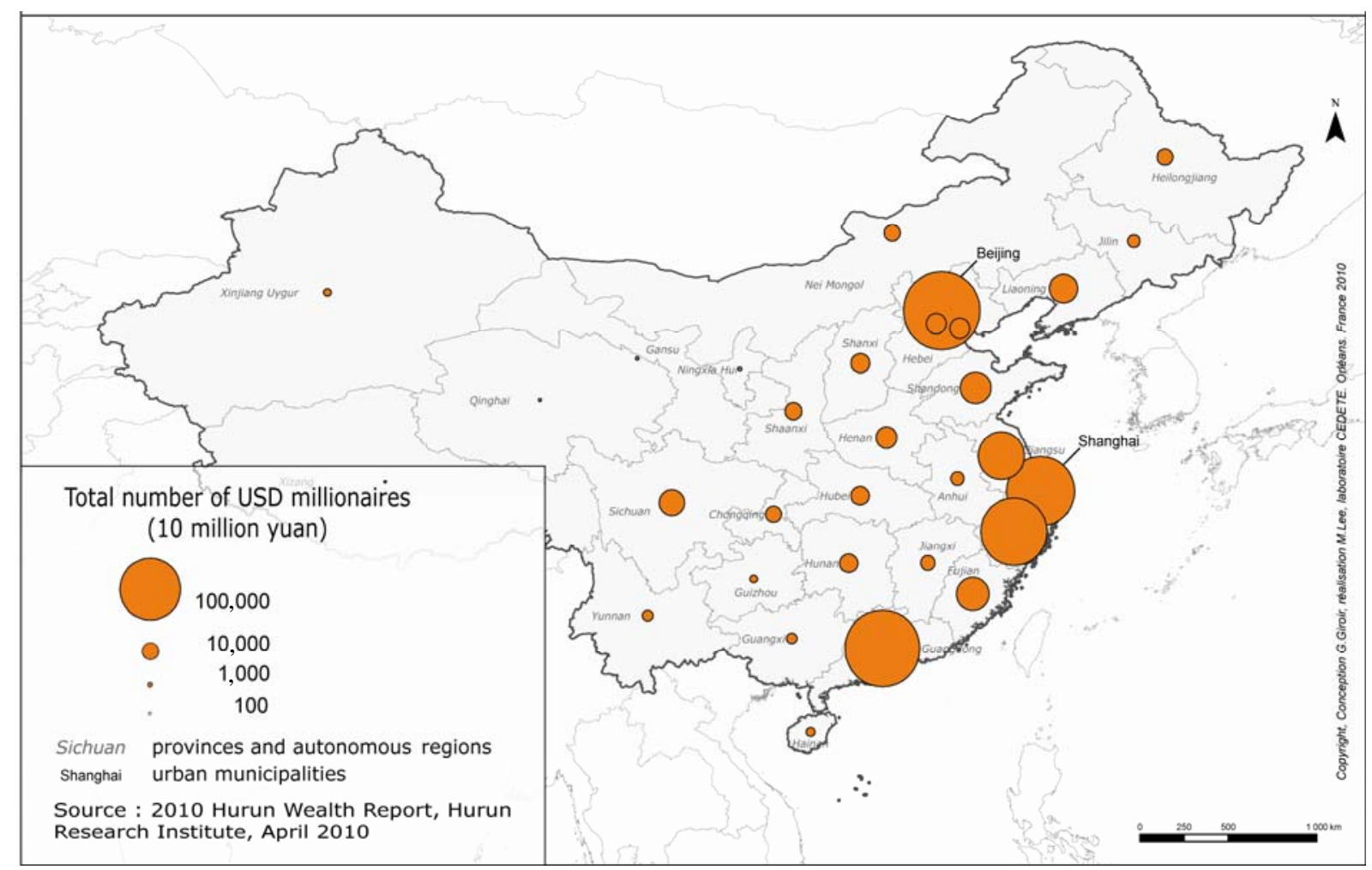

Figure 1. Distribution of the USD millionaires in China by provinces, autonomous regions and urban municipalities (10 million Yuan, 2009).

The super-rich Chinese have rapidly embraced the club practices and the international institutions of their foreign counterparts. As illustrated by the success of ultra-exclusive concierge company quintessentially. Originally, established in London in 2001, it has established subsidiaries in Beijing, Shanghai and Hong Kong. One major motivation for super-rich here is to maintain or create relationships, in line with the tradition of "guanxi". They attend the most exclusive clubs like the famous Yongfoo Elite in Shanghai or Chang a Club in Beijing. Dating sites for super-rich are beginning to emerge. This is the case of Golden Bachelor (Farrar, 2010).

In total, the term "nouveau riches" or "hyper-rich" seems restrictive. According to the monthly magazine Hurun Report quoted by China Daily, the millionaires and billionaires do not just want to be rich, but to become a sort of “upper class” or "new aristocracy” (Yu, 2009).

\section{Being Hyper-Rich in a "Market Socialist Economy": A Status at Risk}

In a Confucian society and a still Communist regime, it is obvious that the phenomenon of super-rich and ultra-luxury features heavy social and political issues. Released statistical figures represent only mere estimates because some of the rich under-declared their assets. Everyone remembers that the publication in 1999 by Forbes magazine of the list of the richest Chinese, nicknamed the "death list" has been followed by a wave of tax adjustments and imprisonment.

Being hyper-rich in China is still far from a comfortable situation. More and more rich people tend to emigrate abroad to enjoy greater political security and provide better educational opportunities for their children. Some of them aim at a second citizenship (e.g., Kitts and Nevis) to get a visa to the United States or Great Britain. Indeed, the Chinese nouveau riches are limited by their passport that makes it difficult conditions for obtaining visa. Moreover, buying a property abroad is a way to secure their wealth. More generally, the super-rich face a 
major contradiction: To do business in China, they need government help, but it often involves committing economic crimes. It captures all the specificity of this phenomenon of hyper-enrichment in a hybrid context of "market socialist economy".

The meteoric rise and subsequent fall of billionaires has become a classic phenomenon in China. The woes of Huang Guangyu, a symbol of success of the private enterprise and more widely of the "Chinese dream", resulted in a bombshell. Starting from nothing, the son of small rice farmers from Guangdong founded the company Gome (Guomei), the current Chinese No. 1 of the distribution of electronic equipment, with 1,100 stores and over 300,000 employees. Barely 40, he became the richest man in China (estimated fortune of \$ 5 billion), before being arrested in November 2008 and be sentenced in May 2010 to 14 years in prison. The super-rich are taking advantage of the system so far, they can also be victims.

\section{The Perception of Hyper-Rich and the Ultra-Luxury in China: An Ambivalent Image}

The famous slogan of Deng Xiaoping in 1992 "It is glorious to get rich" does not mean that the phenomenon of the rich, and all the more so the super-rich, has a broad social acceptance. The rich also generate a negative reaction, even violent response from the public. This resentment led to a common expression in the media: "fenfu" or "choufu" ("hate of the rich"). Other terms are often used: "rich corrupt", "stinking rich". A poll by the newspaper China Youth Daily and sina.com website conducted in September 2007 reveals that over 70\% of respondents believe that the rich are immoral and do not deserve respect. Only $4 \%$ believe that the rich are good. It is obvious that the hatred of the rich finds a part of its origin in the enormous social inequalities observed in China. Similarly, hyper-conspicuous consumption appears as a provocation in a society still characterized by low wages, difficult working conditions and sometimes unemployment.

Wealth in itself does not seem to be the heart of the criticism, but rather the values of the rich and the conditions for obtaining their wealth. Traditionally, Chinese society values education more than wealth. Lack of education and training of many nouveau riches worsens the problem. The idea prevails that the rich have accumulated their fortunes on the backs of the rest of society. This is particularly true of fortunes from real estate speculation, one of whose effects is to increase the cost of housing prices for the rest of society. Businessmen are well qualified to fast "highwaymen" ("jianghu haoke") and are charged with looting the country. Research by Xiao Zhao (University of Science and Technology, Beijing), one of the leading economists in China, has fully supported this view by demonstrating that persons having getting rich the fastest are those who have relationships with power.

The image of the rich in China is even worse than several scandals have involved CEOs part of the largest fortunes in China. The Chinese opinion is not anti-wealth but anti-corruption, in addition, it apprehends enrichment through personal behavior. It raises the question of ethics but also of humanness, including solidarity and compassion. Half of the richest does not form part of the most generous philanthropic donors. The scandal caused by the non-payment (real or perceived), and all the more so, the suspected diversion of fund-raising by the film star Zhang Ziyi to the earthquake victims in Sichuan in May 2008 show the great sensitivity of the issue. The other big scandal over the racy photos of the actress with her boyfriend on the island of St. Bart reflects the social pressure in China's morals.

The behavior of some ostentatious nouveau riches also arouses disapproval. The producer of blockbusters Wang Zhongjun may serve as an archetypal example. He drives a silver Mercedes and a red Ferrari, he owns a villa in $6,000 \mathrm{~m}^{2}$ in the northern suburb of Beijing and an art collection worth more than \$ 30 million, he also 
maintained a stable with 60 horses in Ireland, France and Kentucky. In late 2009, a girl from a wealthy family of Chongqing has spent millions of Yuan to welcome home her dog. In Nanjing, young people organized racing cars blocking the traffic.

\section{The Hyper-Luxurious Gated Communities: A Typology}

One of the most spectacular consumption of hyper-rich is buying hyper-luxurious villas. This "residential hyper-luxury" is a subject of scientific study in itself. These hyper-luxurious residential enclaves of villas are grouped into closed and secure gated communities but differ significantly from common luxury gated communities. Beyond their architectural aspect, these extreme forms of residential offer the opportunity to capture some elements of the imagination of the rich, their dreams and their values.

\section{The Most Expensive Gated Communities in China: Methodological Elements}

The concept of hyper-luxurious gated communities has no specific limit. A restrictive way to identify is to refer to the list of the ten most expensive villas in China. In recent years, a list of the ten most expensive zones of villas has been published by the official Chinese press (see Table 2).

Table 2

List of the Most Expensive Gated Communities in China (2006)

\begin{tabular}{|c|l|c|}
\hline Rank & \multicolumn{1}{|c|}{ Premises } & City \\
\hline 1 & Sunville (Shanghai Ziyuan) & Shanghai \\
\hline 2 & Sandalwood (Tangong) & Shanghai \\
\hline 3 & Mission Hills (Guanlanhu) & Beijing \\
\hline 4 & Beijing Rose Garden (Meigui yuan) & Guangzhou \\
\hline 5 & Favorview Palace (Huijing Xincheng) & Beijing \\
\hline 6 & Forest Hills (Dongshan shu) & Shanghai \\
\hline 7 & Shanghai Forest Manor (Xijiao zhuangyuan) & Beijing \\
\hline 8 & Palace of Fortune (Caifu Gongguan) & Beijing \\
\hline 9 & Green Sea Manor (Bihai Fangzhou) & Beijing \\
\hline 10 & Purple Jade Villas (Ziyu Shanzhuang) & \\
\hline
\end{tabular}

Note. Source: Anonymous (2006, June 14). Top 10 Chinese luxury houses in China. China Daily.

The distribution by the Chinese government of this kind of information not very politically correct is not easy to interpret. It may function to inspire the public, maintain the "Chinese dream", or more cynically draw up the real estate prices. But the concept of "the most expensive villa" is rather ambiguous: It does not specify if this is the highest average price of a zone of luxury villas, the maximum cost of one or a few villas, or the price per $\mathrm{m}^{2}$. Besides, the emergence of new real estate projects to an ever more extreme luxury partially modifies the overall standings. In 2010, the most luxurious villa would be in the new complex Guangzhou the World (60,000 Yuan $/ \mathrm{m}^{2}$ ).

Given these methodological remarks, the goal here is not following the list of the ten most expensive villas, but inspiring from them to establish a typology of the main forms of residential hyper-luxury and identify factors to explain their uniqueness.

Indeed, all these hyper-luxurious gated communities have a number of similarities (location, sale price, living area, architectural style, level of amenities...) that make them exceptional residential forms. But it is possible to classify them under distinctly different categories. 


\section{Imperial Type: Longfor Summer Palace (Beijing)}

One of the most obvious forms of residential hyper-luxury expressed through the reminiscence of the imperial era. The most representative example is certainly the Longfor Summer Palace Splendor (Longhu Yiheyuan zhu) Villas. The analysis of the advertising site reveals its uniqueness. The location of these villas is closely linked to the high places of power in imperial China. They are situated at the crossing point of three famous imperial gardens created by the Qing emperors, Kangxi, Yongzheng and Qianlong. Indeed, they are just 50 meters east of the Summer Palace, south of Yuanmingyuan and West of Guchang chunyuan. In paradoxical but highly symbolic continuity between imperial China and Communist China, hyper-luxurious character of Longfor is also due to its close proximity to the campus of the Central Party School (Dangxiao) which trains executives of the PRC.

It is written that "the dream of the imperial family still continues" ("zai zhi xuchuan shijiazu mengxiang”). "The Last Emperor is set at this place, with Longfor villas, glory continues”. A unique historical view is added: "hidden 300 years, 60 years of fermentation (yunniang), finally a great celebration of the Chinese family". In other words, Longfor remained hidden for 300 years since the creation of the Summer Palace by Emperor Qianlong in 1750. Then, between 1949 and 2009, occurred the maturation phase; here the chronology is cleverly modified. The Maoist period is not mentioned as such, the period of openness and reforms either. In the manner of a great wine, the project Longfor embodied the quintessence, the outcome but also the overcoming of the imperial legacy. It is stated that the developers have taken twelve years to select the ideal location according to the principles of "fengshui", but also the "wisdom" ("zhihui”). The site has a "fengshui" with exceptional concentration of imperial shrines but also of natural elements such as the Yanshan Mountains to the North, various lakes (e.g., Kunming Lake of Summer Palace) and parks.

Here, there are not houses, but "little palaces" (“xiaoxing gongdian”) and "houses of the king”. The architecture is inspired by the Summer Palace buildings, in particular their doors, roofs and windows. But the 91 villas each also have a garage for 11 cars, a private museum of $500 \mathrm{~m}^{2}$, a private club and three presidential suites. Their living area varies between 1,000 and 3,600 $\mathrm{m}^{2}$, developed over four floors, and are integrated into a vast complex of $97,809 \mathrm{~m}^{2}$. The use of limestone facade imported from France and Portugal is intended to add to the feeling of grandeur. The gardens were designed according to the principle of construction of the imperial gardens.

\section{European Classic Style Type: Sandalwood (Shanghai)}

Another form of super-luxury residential villas is represented by Sandalwood (in Chinese Tangong, "Palace of Sandalwood”). This is a collection of 18 upscale villas located in Shanghai, Changning district. Opened in December 2005, it is the first complex of luxury villas located within the dense zone of Shanghai. Since the Ming Dynasty, sandalwood became customary to make the furniture of the imperial palaces. It is extremely slow growing, hardness, density, and very dark color symbolize the nobility, the rarity and magnificence. It is also a religious value. The smoke is supposed to have the power to drive out evil spirits, and chips are burned in temples during religious ceremonies.

Selling prices show very high levels from 60 million Yuan to 98 million Yuan (2009). The villas are located in a site of $47,384 \mathrm{~m}^{2}$, of which $31,200 \mathrm{~m}^{2}$ of floor space for all villas. Each villa has a living area of between 1,500-1,800 $\mathrm{m}^{2}, 2,500 \mathrm{~m}^{2}$ with the garden. Each has an indoor pool and, more rarely, a private theater. The hyper-luxury classic based on the values of grandeur, nobility, exclusivity, timelessness and permanence. Sandalwood is an ensemble of small palaces and manor concentrating 18 European classical styles. The main 
countries represented are: France (Fontainebleau, Riviera...), UK (Imperial, English Park, Georgian), Italy (Florence, Tuscany). The gardens themselves, designed by the company Collin Belt (Hong Kong), are of classical type. The rate of green in Sandalwood Villas is $40 \%$.

More generally speaking, a well-represented variation is represented in China by the hyper-luxurious villas of the French type. In this case, there are most often houses that are similar to castles. The most notable example is constituted by Palais de Fortune (Beijing), a comprehensive set of 172 nineteenth-century French chateaux of at least $1,500 \mathrm{~m}^{2}$ along the Wenyu River.

\section{Ecological Type: Sunville (Shanghai)}

Several villas have their hyper-luxury features to their natural environment. This applies, for example, to Forest Hills (Beijing), consisting of 155 villas in the hills with valleys, lakes, and rivers. It is the same case with the 244 villas of Forest Manor (Shanghai), or the Purple Jade Villas (Beijing) (see Figure 2).

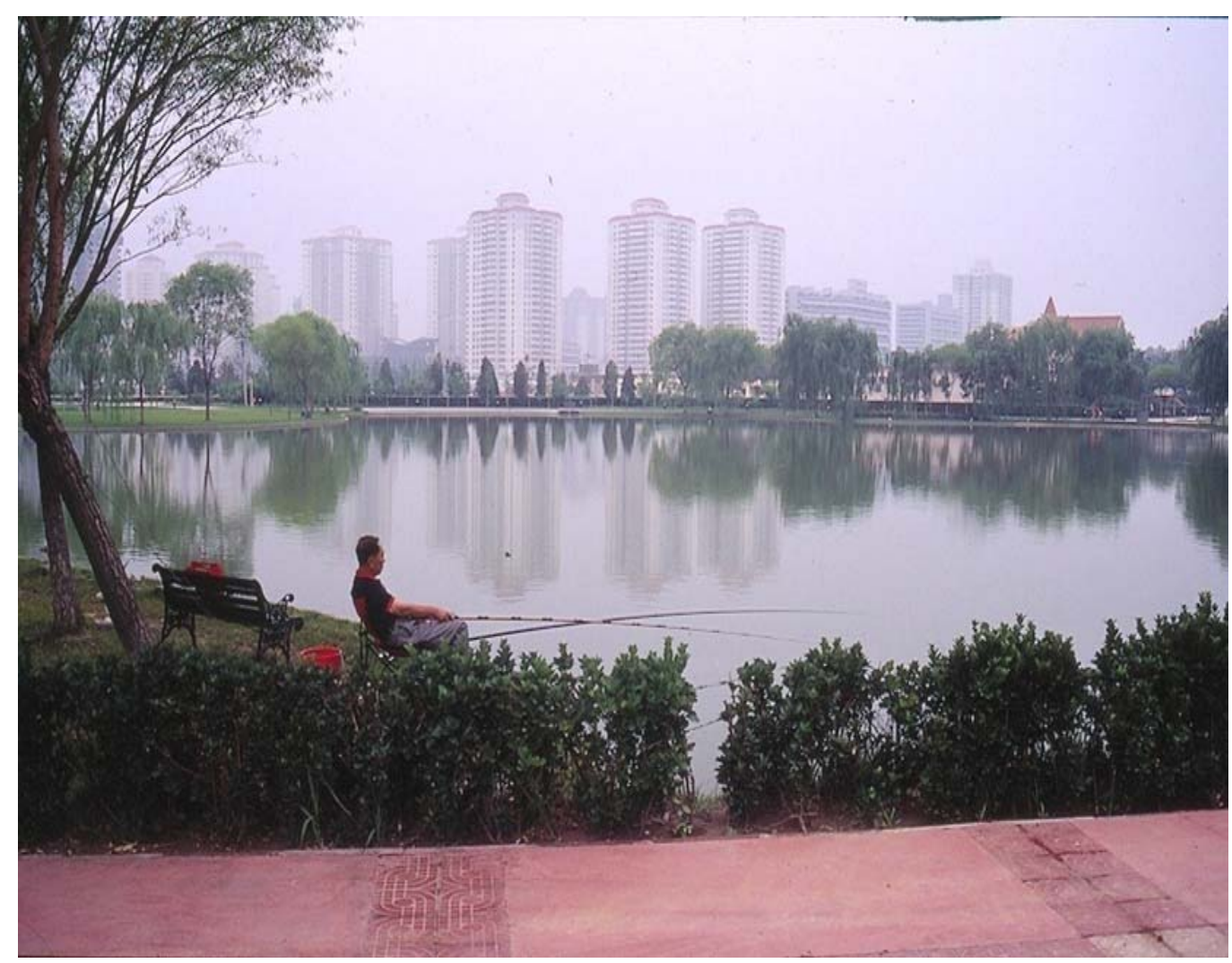

Figure 2. The Purple Jade Villas, an oasis of nature in the heart of Beijing. Photo: G. Giroir.

But the most hyper-luxurious gated communities from ecological type are represented by Sunville (Shanghai) (see Figure 3). The Villas Sunville (Shanghai Ziyuan) are known in China for having achieved record sale prices. In 2003, one of them was the most expensive of China: Sunville No. 1 House or "King House" was sold 130 million Yuan to a Chinese overseas. Two Sunville villas belonging to the "second generation property king” built in 2008 were sold respectively 247 and 180 million Yuan in March 2010 (Lee, 2010). The most expensive, Villa 99 is inspired by the architecture of the Bund. 


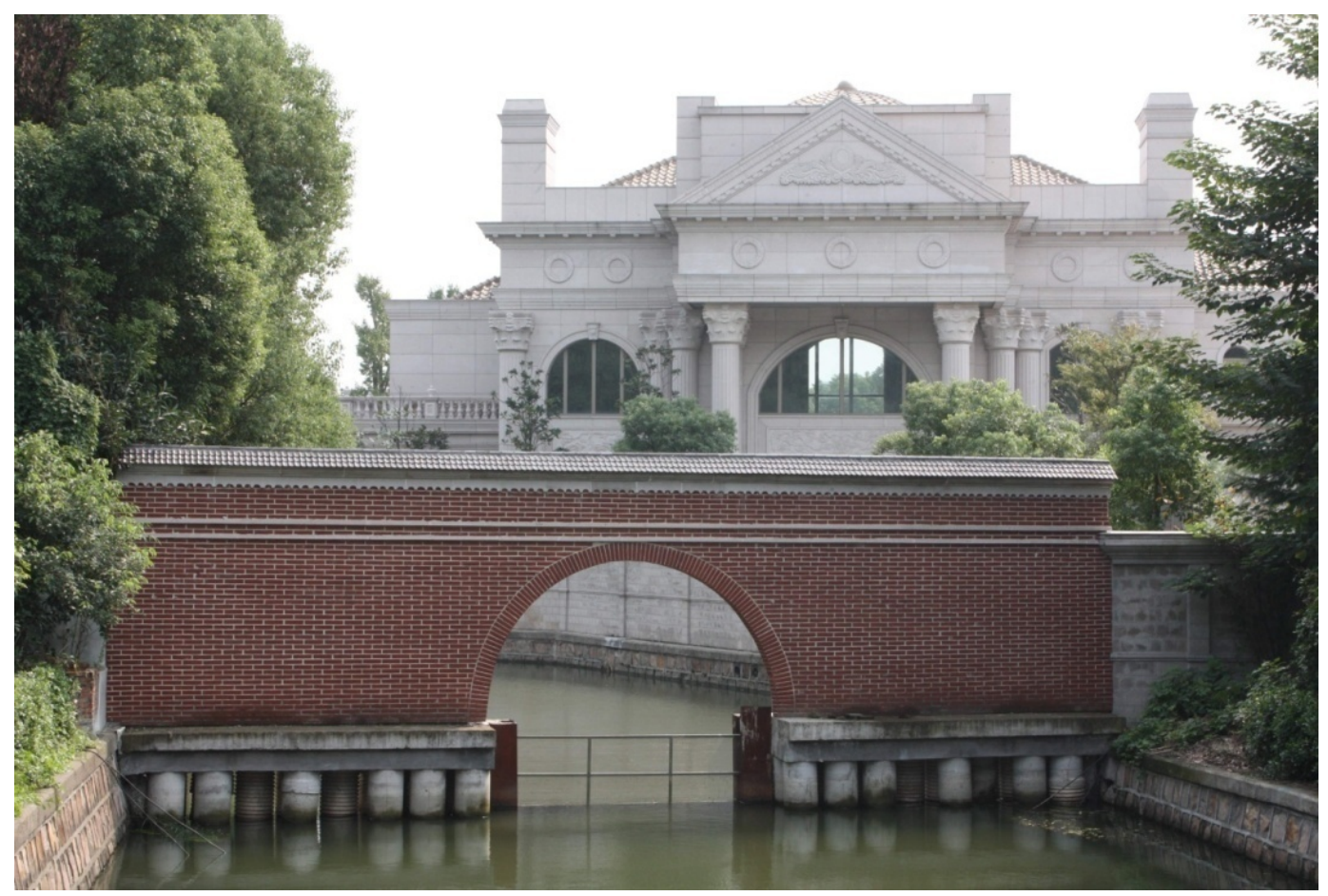

Figure 3. A villa in Shanghai Ziyuan. Photo: G. Giroir.

The uniqueness of these 268 villas is largely due to their site. The Villas Sunville are indeed located next to the Sheshan National Tourism Zone, including the Sheshan National Forest Park, protected area created in 1995 by the State in the Southwest of Shanghai. This residential enclave of $920,000 \mathrm{~m}^{2}$ (20,000 $\mathrm{m}^{2}$ of water) is located only $30 \mathrm{~km}$ from Shanghai in the Songjiang district. The average height of ground of the Chinese economic capital does not exceed $3 \mathrm{~m}$ above the sea because of its location in the Yangtze delta plain. The top of Sheshan rises to $97 \mathrm{~m}$; hence the Shanghainese nickname "the mountain". Unique natural hilly forest zone of the delta, the area of $64 \mathrm{~km}^{2}$ is considered the city's backyard, which provides clean air and tranquility. The rich residents of Sunville have what Shanghainese have not: the nature.

Each owner of Shimao Sheshan Villas also has a private island of 1,000 $\mathrm{m}^{2}$. In total, 13 islands are connected by bridges (Anonymous, 2006). All waterfront villas have a private marina with a dock and the ability to have a yacht.

Some villas of Shanghai Ziyuan also have a view on the famous Roman Catholic Basilica of Sheshan, the largest in the Far East and a place of pilgrimage for Catholics from South East Asia for over 100 years (see Figure 4). The Sheshan Mountain is also a gathering place for Buddhism and Taoism.

The architecture of the villas has been conceived by internationally renowned architects (Wright). The developer (Bestland Property Co. Ltd.) is from Singapore origin. Some villas reach 3,183 $\mathrm{m}^{2}$ and have an international outdoor tennis court and indoor classified "top international private pool”. Residents have access to 18 holes golf course and at exclusive Sheshan International Golf Club, Mecca for golf in Asia. With multiple services (nursery, school, shopping center, post office, banks, health center...), Sunville is a real autonomous city on the outskirts of Shanghai. 


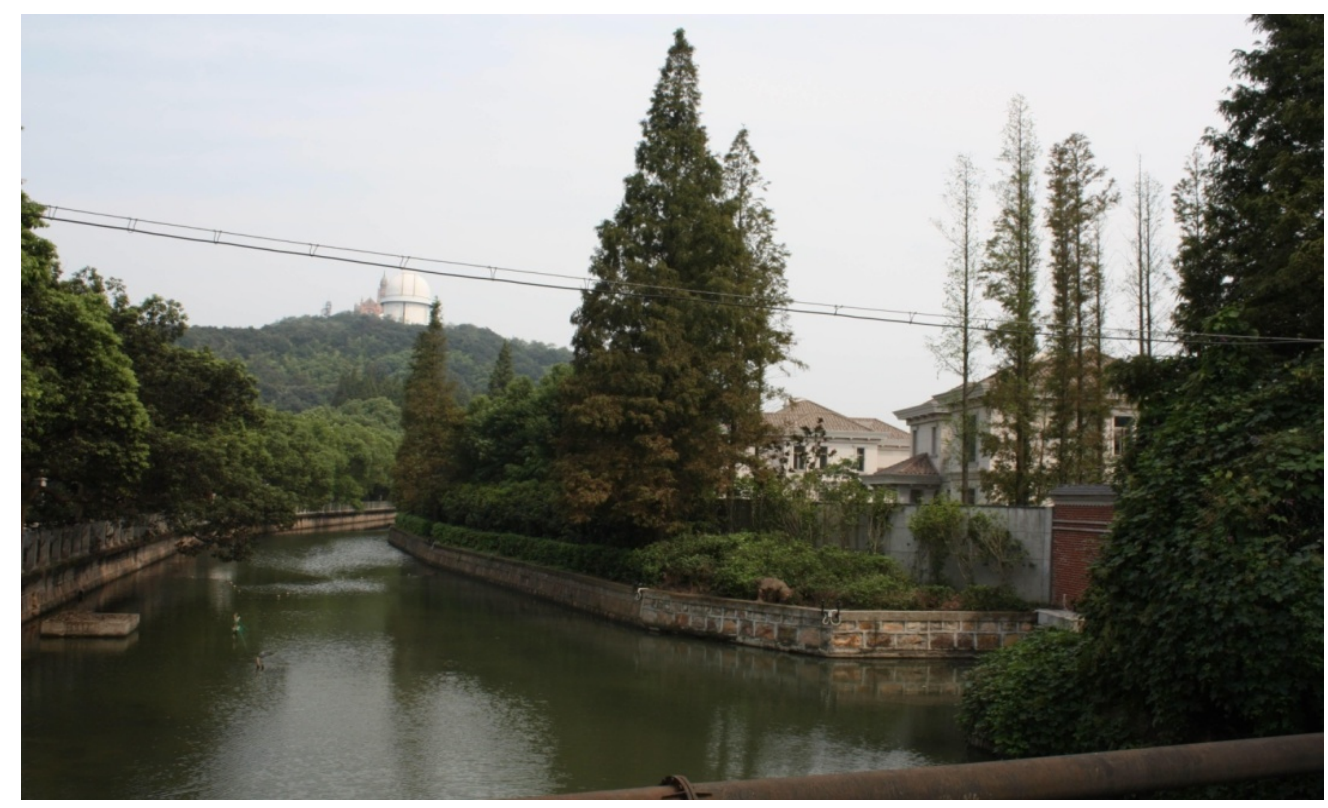

Figure 4. Shanghai Ziyuan villas, basilica of Sheshan and observatory. Photo: G. Giroir.

\section{Hyper-Luxurious Gated Golf Communities: Mission Hills (Shenzhen)}

The integration of a golf course within the gated communities is often a key element of luxury (Giroir, 2007a). Several ultra-luxurious gated communities are special types of gated golf communities, as Favorview Palace (Guangzhou) or mostly Mission Hills (Shenzhen). Opened in 1995, Mission Hills (Guanlanhu gaoerfu julebu, “Golf Club of lake Guanlan”), in an area of $20 \mathrm{~km}^{2}$ located just 30 minutes' drive north from Shenzhen and Hong Kong. With twelve golf courses of 18 holes designed by Jack Nicklaus, or 216 holes in total, it is the largest golf in the world. The country club is also the most luxurious of Asia. Initially, there was no plan to build villas. The decision was taken both to satisfy golfers' eager to indulge their passion on a daily basis, but also to make profitable the golf course itself (Taylor, 2004).

The construction program of 224 villas is concentrated on Mission Hills in Residence, an area of 4.6 ha open in May 2004. There are three types of villas. The most luxurious ("Presidential Commons") occupy 1,528 $\mathrm{m}^{2}$ with 4,853 $\mathrm{m}^{2}$ of garden, for a sale price of $\$ 22$ million (see Figure 5). They mix the style of the Italian Renaissance and the "modern tropical Hawaiian". Those of $877 \mathrm{~m}^{2}$ (with 2,180 $\mathrm{m}^{2}$ of garden) are available for $\$ 13$ million, less large (700 $\mathrm{m}^{2}$ and 1,300 $\mathrm{m}^{2}$ of garden) will sell \$ 9 million. One such concentration of wealth explains that this gated golf course community is highly protected. Active safety is ensured by 400 guards, former officers from the Zhongnanhai de baohan, which trains military elite in Beijing, and 60 dogs. Mission Hills employs no less than 4,000 people, including about 2,000 caddies.

Other types of hyper-luxurious gated communities less represented could be distinguished, especially in the ultra-contemporary styles (e.g., Fragrant Hills) or seaside resort (e.g., Shenzhen OCT East Horizon).

\section{Conclusion}

The phenomenon of the hyper-rich and the hyper-luxury is probably the most dramatic transition from the former society without class toward the current highly differentiated society. It has strong features related to transitional context of China today. The process of hyper-enrichment reflects the current hybrid economic system of China, with both its effectiveness at creating wealth but also its pathologies and its ambiguities. 


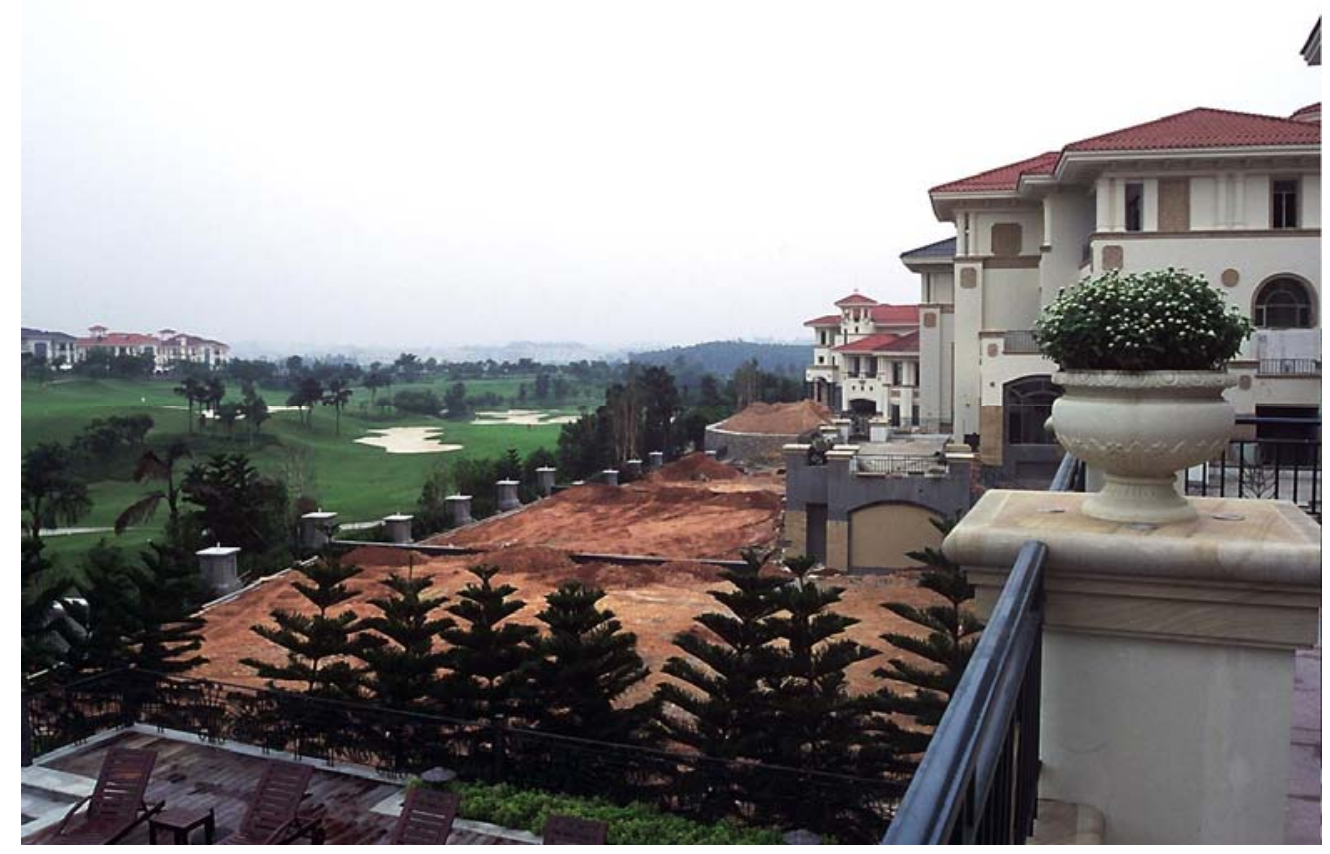

Figure 5. Hyper-luxurious gated golf villas in Mission Hills (Shenzhen). Photo: G. Giroir.

The phenomenon of hyper-rich and residential hyper-luxury raises several questions, particularly in terms of sustainability. How a Confucian and Communist society can manage politically and long-term such a phenomenon of personal enrichment? May it possible that the pursuit of accelerated hyper-enrichment and the formation of a new super-wealthy aristocracy carried out at constant institutional framework? Does the hyper-enrichment and its associated phenomena remain an isolated and marginal phenomenon, or rather a kind of cancer that is eating the head of the State and that, due to various political maneuvers and false sense of impunity among the new aristocracy, will be treated with drastic action only when it is widespread, too late? We know the Chinese proverb: "the fish rots from the head".

The Chinese government seems fully aware that the hyper-enrichment is a more and more political issue. The slogan "allowing some get rich first" ("rang yibufen ren xian fuqilai") no longer seems sufficient to ease public opinion. To improve the level of social acceptance towards the rich, Li Hongmei, regular columnist official newspaper People's Daily, goes much further: It proposes a proactive policy towards the eradication of egalitarian attitudes in Chinese opinion (Li, 2009). In this case, one might nevertheless wonder about the true political nature of a Communist regime whose propaganda is to promote the dogma of social inequality. Can the propaganda of a still Communist regime do love the super-rich? More than a mere ideological aggiornamento, this is a true reversal of values.

The hyper-enrichment of a small minority of the Chinese society poses also an ethics issue. It raises the central issue of relations between the spheres of money and power. Suffice to say that their possible disconnection goes against a very deep and widespread culture oriented toward the gift for service. This phenomenon seems to call for a transition of the pragmatism and opportunism in the current business style toward an ethics based on values. To be more accepted, it seems necessary that the hyper-rich appear less like players eager to accumulate face ("mianzi") by all means, a bit boorish and selfish opportunists exploiting loopholes in the current system to incorporate more of an business ethics made of minimal transparency, virtue and solidarity with the rest of society. 
But the defects of the hyper-rich are the result of a state system characterized by a profound ambiguity. That is the reason for the virtue of the rich must pass first through a greater virtue of the state itself.

\section{References}

Anonymous. (2006, April 28). Fancy a villa? Be ready to fourk out \$31.25 m. China Economic Net.

Anonymous. (2010, April). 2010 Hurun Wealth Report. Hurun Research Institute.

Bondois, C. (2007). Origins and powers of the new rich. China Perspectives, 1. Hong Kong.

Farrar, L. (2010, January, 26). China’s super-rich look for love online. CNN.

Giroir, G. (2002, December). The phenomenon of gated communities in Beijing, or the new forbidden cities. In Bulletin de l'Association de Géographes Français. 423-426, Paris.

Giroir, G. (2003). Gated communities, clubs in a club system. The case of Beijing (China). Paper presented at the Conference of Glasgow Gated communities. Retrieved from www.gla.ac.ak/departments/urbanstudies/gated/gatedpaps/gatedconfpaps.html

Giroir, G. (2005). "Hard enclosure” and "soft enclosure” in the gated communities: Some theoretical perspectives and empirical evidence in China. Paper presented at the International Symposium of Pretoria (South Africa), Territory, control and enclosure: the ecology of urban fragmentation, February 28-March 3. Proceedings available on a CD, 20.

Giroir, G. (2006a). Les Villas Yosemite, miroir du capitalisme émergent ? Une gated community à l'américaine à Pékin. In Yosemite villas-mirror of emerging capitalism? An American-style gated community in Beijing. China Perspectives, 64, 13-23, Hong Kong.

Giroir, G. (2006b). The Purple Jade Villas (Beijing), a golden ghetto in red China. In K. Frantz, G. Glasze, \& C. Webster (Eds.), Private cities: Global and local perspectives. London/New York: RoutledgeCurzon, 142-152.

Giroir, G. (2006c). The Fontainebleau Villas (Shanghai), a globalized golden ghetto in a Chinese garden. In F. Wu (Ed.), Globalization and the Chinese city. London/New York: RoutledgeCurzon, 208-225.

Giroir, G. (2007a). Spaces of leisure: Gated golf communities in China. In F. Wu (Ed.), China's emerging cities: the making of new urbanism. London/New York: Routledge Curzon, 235-255.

Giroir, G. (2007b). Socioterritorial fractures in China: The unachievable “harmonious society?” China Perspectives, 3, 83-91, Hong Kong.

Giroir, G. (2008a). Beyond gated communities: Phoenix City (Canton), the first private city in China. Urbanisme, 361, 33-38, Paris.

Giroir, G. (2008b). The spread of Chinese-style gated communities: The cases of Yijun and Guantang, Beijing. In C. Vallat (Ed.), Pérennité urbaine. Ou la ville par-delà ses métamorphoses, II, L’Harmattan: Paris, 85-98.

Giroir, G. (2009a). China: nouveaux riches and luxury gated communities in China. In T. Paquot (Ed.), Ghettos de riches (Ghettoes for the Rich). Paris: Perrin, 224-240.

Giroir, G. (2009b). The phenomenon of gated communities in China: Assessment and prospects (1978-2008). Sixteenth International Seminar on Urban Form (ISUF 2009), China South University of Technology/Urban planning bureau of Guangzhou, Guangzhou (China), Proceedings available on a CD, 15.

Lee, R. (2010, March 10). Shanghai sees more record-breaking residential transactions. Retrieved from The EdgeProperty.com

Li, H. M. (2009, April 2). Don't hate the rich, be one of them. People's Daily Online.

Lu, P. X. (2008). Elite China: Luxury consumer behavior in China. Wiley-Blackwell.

Pow, Choon-Piew. (2009). Gated communities in China: Class, privilege and the moral politics of good life. Routledge.

Taylor, M. (2004, March 30). Luxury living in Shenzhen simply par for the course. South China Morning Post.

Yu, T. Y. (2009, August 24). Beijing tops Hurun list with 143,000 millionaires. China Daily. 